\title{
GREEN BUILDING AS A DIRECTION OF SUSTAINABLE DEVELOPMENT: ESSENCE, TASKS, PRINCIPLES, BENEFITS, PROSPECTS
}

\author{
V. Bilotil \\ Researcher \\ Institute of Agroecology and Environment Management of NAAS \\ (Kyiv, Ukraine) \\ e-mail:Walya@i.ua
}

The construction industry plays an important role in achieving the UN Sustainable Development Goals and reducing the impact on climate change through the introduction of green building principles. So the article has been devoted to this type of construction as an important area of sustainable development.

The interaction of climate change and construction activities has been substantiated in the article. Tasks and principles of sustainable construction have been analyzed. The economic, ecological and social benefits of green construction have been studied. The difference between traditional and green construction has been described. The current state of development of sustainable construction in Ukraine and the world has been considered. Prospects for green construction in Ukraine have been identified. The urgency and necessity of its implementation in our country have been proved.

Keywords: construction industry, global climate change, ecological construction, green economy, the Sustainable Development Goals.

\section{INTRODUCTION}

Global climate change is one of the biggest problems of the modern world which is a threat to the environment, the economy and human health. As global warming affects all spheres of human life and activity, therefore immediate response measures must be introduced to mitigate the effects of climate change and also improve the ability to adapt to climate-related hazards and natural disasters. If we do not take action now we will soon be close to the limit when global climate change can no longer be stopped and future life on Earth will be threatened.

One of the main sectors of the economy, which significantly affects the climate, is construction. It requires the use of a large number of different natural resources, whose production often has a negative impact on the environment and the course of climate change. In addition, the construction industry is a significant source of emissions of harmful substances, greenhouse gases, etc. At the same time construction and construction industries as a whole are directly dependent on a number of climatic factors (fig. 1).

The construction industry needs urgent adaptation to the existing and expected risks due to global climate change. Most of the buildings in operation today were designed and built on the basis of climatic parameters that characterized the conditions of the middle of last century, and in modern conditions of extreme climatic loads increases the likelihood of destruction, accidents and catastrophes [1, p. 64].
In this regard, at the global level there is the concept of green building or sustainable building, which aims to reduce the consumption of energy and material resources, as well as to reduce the harmful effects of construction on human health and the environment [2, p. 18].

The construction sector plays a key role in achieving the UN Sustainable Development Goals, given the significant economic, environmental and social impacts and benefits associated with construction products, buildings and infrastructure assets over their life cycle. The World Green Building Council supports the United Nations Sustainable Development Goals, which identify ways to grow economically in the face of global climate change under the motto «promote prosperity while protecting the planet». The introduction of innovative green building technologies allows not only to save energy, water, resources and reduce carbon emissions but also to spread advanced knowledge, create new jobs, strengthen communities, improve health and well-being and much more [1, p. 65].

Therefore, the purpose of this research is to clarify the key characteristics of green building as one of the areas of sustainable development today.

\section{ANALYSIS OF RECENT RESEARCH AND PUBLICATIONS}

The construction industry has a huge negative impact on the environment. Green construction as a modern approach to construction can make the building resource-saving, as comfor- 


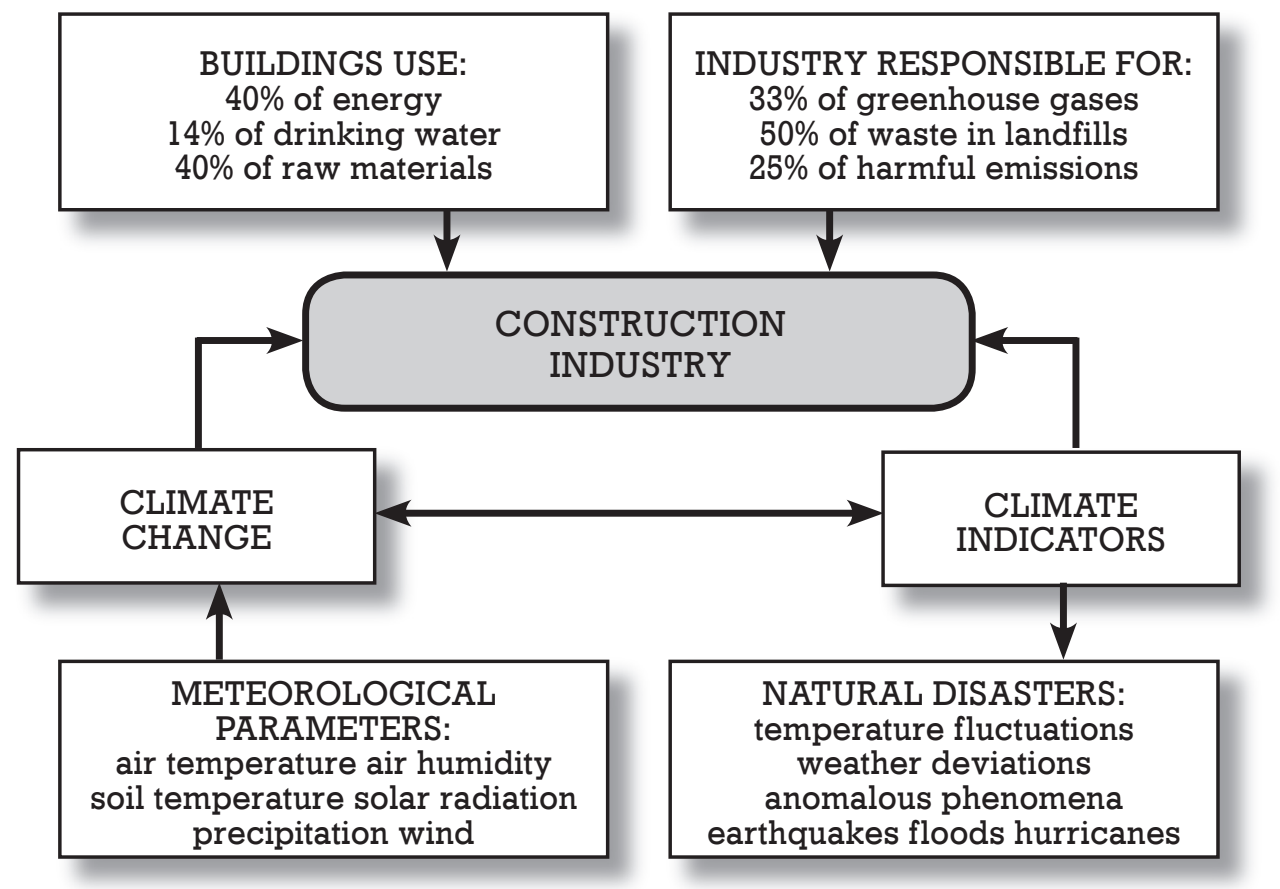

Fig. 1. Interactions between climate change and construction Source: [1, p. 62].

table as possible and with minimal impact on the environment.

Such scientists as Kryvomaz T.I., Savchenko A.M. [1], Orlovska Yu.V., Vovk M.S., Chala V.S., Mashchenko S.O. [2], Bilyk O.A. [3], Orlovska Yu.V., Yakovyshyna T.F., Orlovskyi Ye.S. [4], Mashchenko S.O., Vovk M.S., Aliiev R.A. [5], Danyliuk M.M., Dmytryshyn M.V. [6] and others devoted their research works to the issue of green building.

Taking into account the level of development of ecological construction in the world and especially in Ukraine, we can draw conclusions about the need to study the features of aspects of this type of construction, as they still remain relevant and require new research.

The aim of research work is to explore green building as one of the areas of sustainable development (its essence, tasks, principles, advantages, current state and prospects of development in the world and Ukraine).

\section{MATERIALS AND RESEARCH METHODS}

The theoretical and informational basis of the study is the scientific works of domestic scientists in the field of green building as one of the key areas in achieving the UN Sustainable Development Goals and the collected data from the World Green Building Council.

Research methods such as comparison, analogy, induction and deduction, systems analy- sis and systems approach were used to solve the tasks.

\section{RESULTS AND DISCUSSION}

Sustainable building or green building is the result of a design philosophy that makes a building resource-efficient, most comfortable and with minimal impact on the environment. In other words, each stage of green construction is carried out in accordance with environmental expediency. Usually green building methods can be integrated at any stage of construction: from design and construction to reconstruction and destruction. However, the greatest benefits can be derived if an integrated green approach is applied from the early stages of the construction project [3, p. 53].

Green construction expands and complements traditional construction and indeed has a number of advantages. Table 1 shows this in more detail.

It is clear that the cost of building a green structure may be higher than its construction in the traditional format, but operating costs, depending on the design solutions, are $50-90 \%$ lower [3, p. 55].

The practice of green building expands and complements the classic building design with the concepts of economy, usefulness, durability and comfort, and the construction and operation process - by reducing the negative impact of 
Comparative characteristics of traditional and green construction

\begin{tabular}{|l|l|l|}
\hline \multicolumn{1}{|c|}{ Indicators } & \multicolumn{1}{c|}{ Green construction } & \multicolumn{1}{c|}{ Traditional construction } \\
\hline \hline Electricity consumption & Low & High \\
\hline Indoor environmental quality & Very high & High \\
\hline Emission level & Low & High \\
\hline Waste management system & Highly effective & Effective \\
\hline Building materials & Environmentally-friendly & Environmentally-unfriendly \\
\hline Design practices & Complex & Normal \\
\hline Feasibility & $>5 \%$ above the threshold & threshold value \\
\hline
\end{tabular}

Source: [3, p. 54].

the structure on the environment and human health. Although new green building technologies are constantly changing and improving, the main tasks of green building are [4, p. 368] (fig. 2):

The development and implementation of green building standards stimulates the development of business, innovative technologies and economy, improves the quality of life of society and the state of the environment. The implementation of the principles of green building will enable the transition to a green economy, which is a part of the concept of sustainable development and has considerable potential. It allows solving current global problems and solving very specific problems: resource saving, improvement of financial and economic performance of economic entities, reduction of costs of home maintenance, reducing financial risks and costs in the construction and maintenance of buildings, reducing the cost of recycling waste from the construction industry, attracting more investment to the regions through the promotion of green building [6, p. 156].

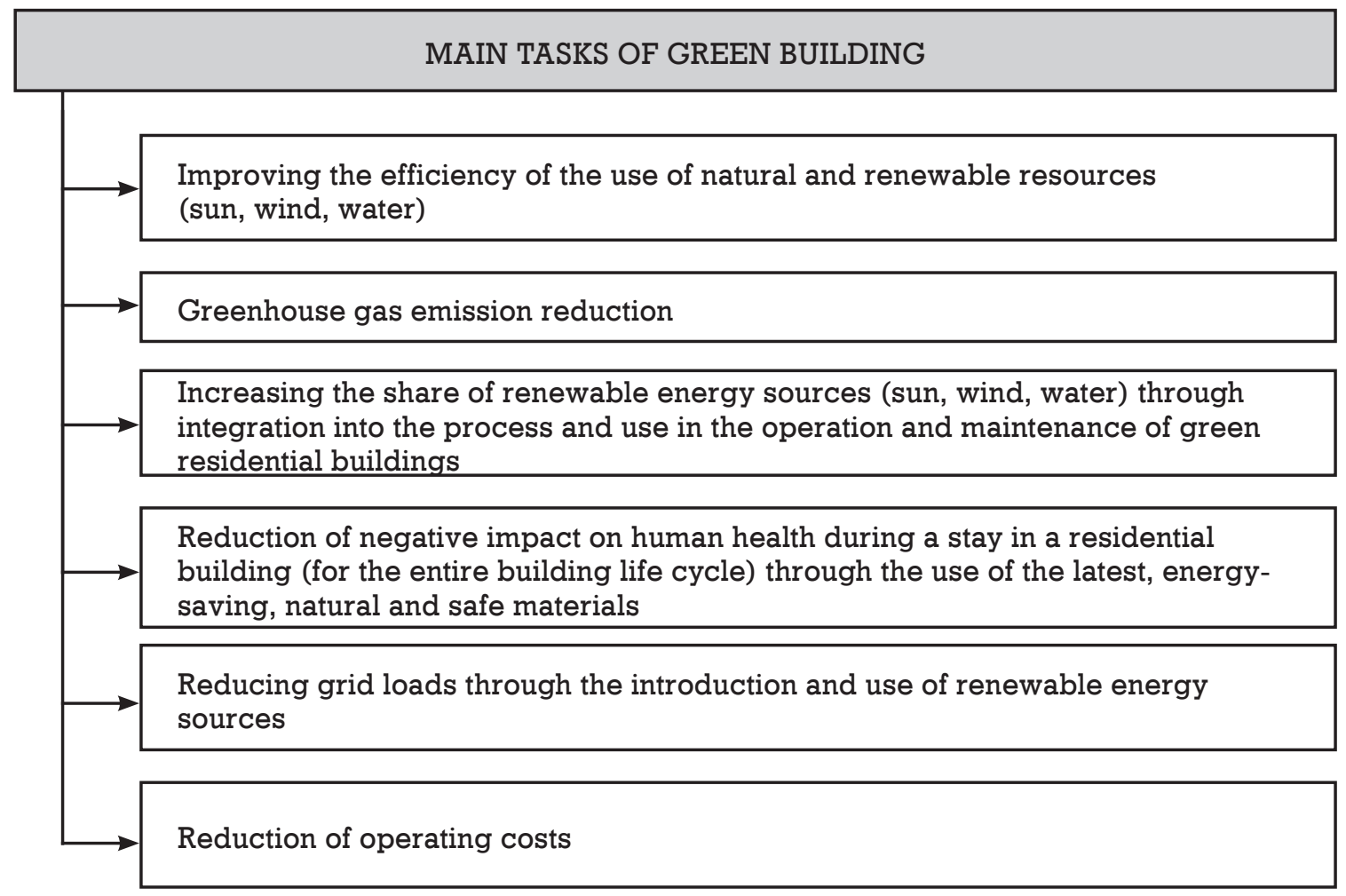

Fig. 2. The main tasks of green building

Source: developed by the author based on [5, p. 224]. 


\section{MAIN PRINCIPLES OF GREEN BUILDING}

optimal choice of place, inclusion of building in common landscape, environment and transport infrastructure

south orientation of windows for maximum use of solar energy and daylight

minimum energy consumption, increased efficiency, alternative energy sources

improvement of thermal insulation, safe use of insulating materials

ventilation with heat return (return of air heat to the heating system)

use of safe, renewable and recycled materials

preference for local materials

harmless automated heating systems

efficient water use, water reuse

improving indoor air quality

beneficial effects on health and well-being

convenient maintenance of buildings

reducing the amount of solid waste during demolition and dismantling of the building

promoting long-term development : environmental, economic and social

Fig. 3. Main principles of green building

Source: developed by the author based on [3].

There are the main principles of green building (fig. 3 ).

The main instrument for implementing green building principles into real estate projects is the so-called green building certification systems. In international practice there are several independent green building certification systems such as Leadership in Energy and Environment Design (LEED), the USA; Building Research Establishment Environmental Assessment Method (BREEAM), the UK. These standards are based on standards for the use of building materials, water, energy and land. Certified buildings cause minimal environmental pollution [6, p. 158].

The world over, evidence is growing that green buildings bring multiple benefits. They provide some of the most effective means to achieving a range of global goals, such as addressing climate change, creating sustainable and thriving communities, and driving economic growth. The benefits of green buildings can be grouped within three categories: environmental, economic and social [7]:

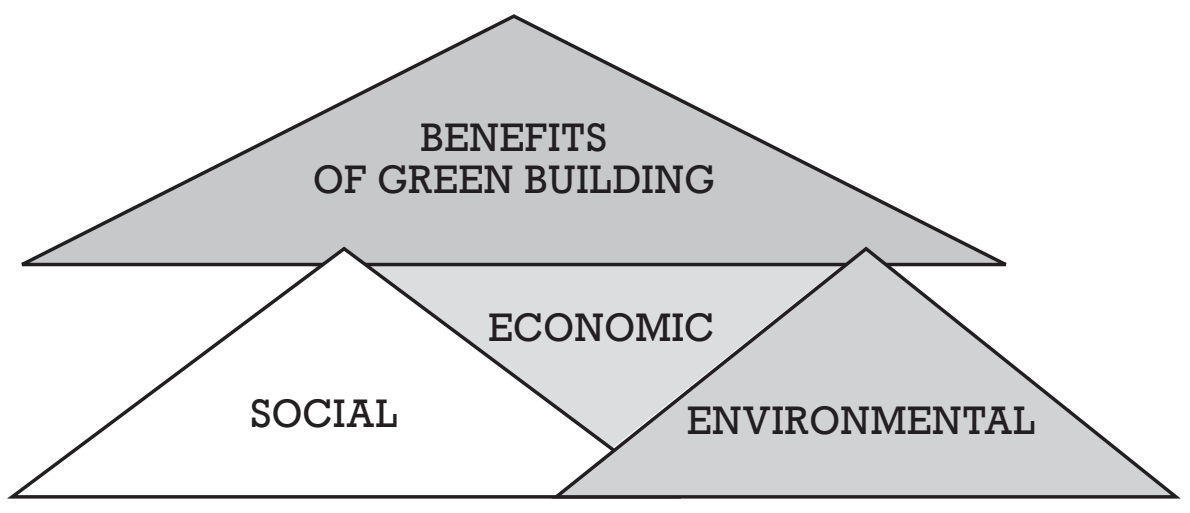

Fig. 4. Benefits of green building

Source: developed by the author based on [7]. 


\section{Environmental benefits}

One of the most important types of benefit green buildings offer is to our climate and the natural environment. Green buildings can not only reduce or eliminate negative impacts on the environment, by using less water, energy or natural resources, but they can - in many cases - have a positive impact on the environment (at the building or city scales) by generating their own energy or increasing biodiversity [7].

At a global level [7]:

- The building sector has the largest potential for significantly reducing greenhouse gas emissions compared to other major emitting sectors - UNEP, 2009.

- This emissions savings potential is said to be as much as 84 gigatonnes of $\mathrm{CO}_{2}\left(\mathrm{GtCO}_{2}\right)$ by 2050 , through direct measures in buildings such as energy efficiency, fuel switching and the use of renewable energy - UNEP, 2016.

- The building sector has the potential to make energy savings of $50 \%$ or more in 2050 , in support of limiting global temperature rises to $2^{\circ} \mathrm{C}$ (above pre-industrial levels) — UNEP, 2016.

At a building level [7]:

- Green buildings achieving the Green Star certification in Australia have been shown to produce $62 \%$ fewer greenhouse gas emissions than average Australian buildings, and $51 \%$ less potable water than if they had been built to meet minimum industry requirements.

- Green buildings certified by the Indian Green Building Council (IGBC) results in energy savings of $40-50 \%$ and water savings of $20-30 \%$ compared to conventional buildings in India.

- Green buildings achieving the Green Star certification in South Africa have been shown to save on average between 30-40\% energy and carbon emissions every year, and between $20-30 \%$ potable water every year, when compared to the industry norm.

- Green buildings achieving the LEED certification in the US and other countries have been shown to consume 25 per cent less energy and 11 per cent less water, than non-green buildings.

\section{Economic benefits}

Green buildings offer a number of economic or financial benefits, which are relevant to a range of different people or groups of people. These include cost savings on utility bills for tenants or households (through energy and water efficiency); lower construction costs and higher property value for building developers; increased occupancy rates or operating costs for building owners; and job creation [7].

At a global level [7]:

Global energy efficiency measures could save an estimated $€ 280$ to $€ 410$ billion in savings on energy spending (and the equivalent to almost double the annual electricity consumption of the United States) - European Commission, 2015.

At a country level [7]:

Canada's green building industry generated $\$ 23.45$ billion in GDP and represented nearly 300,000 full-time jobs in 2014 - Canada Green Building Council / The Delphi Group, 2016.

Green building is projected to account for more than 3.3 million U.S. jobs by 2018 - US Green Building Council / Booz Allen Hamilton, 2015.

\section{At a building level [7]:}

Building owners report that green buildings - whether new or renovated - command a 7 per cent increase in asset value over traditional buildings - Dodge Data \& Analytics, 2016.

\section{Social benefits}

Green building benefits go beyond economics and the environment, and have been shown to bring positive social impacts too. Many of these benefits are around the health and wellbeing of people who work in green offices or live in green homes [7].

- Workers in green, well-ventilated offices record a 101 per cent increase in cognitive scores (brain function) - Harvard T.H. Chan School of Public Health / Syracuse University Center of Excellence / SUNY Upstate Medical School, 2015.

- Employees in offices with windows slept an average of 46 minutes more per night American Academy of Sleep Medicine, 2013.

- Research suggests that better indoor air quality (low concentrations of $\mathrm{CO}_{2}$ and pollutants, and high ventilation rates) can lead to improvements in performance of up to 8 per cent Park and Yoon, 2011.

Green building, creation of green buildings is a practice of construction and operation of buildings whose main purpose is to reduce energy and material consumption throughout the life cycle of a building: from site selection to design, construction, operation, repair and demolition [4, p. 369].

Another important task of green construction is to preserve or improve the quality of buildings and the comfort of their internal environment. These statements significantly complement the standard, conventional construction with concepts such as economy, durability and comfort. In addition, environmentally friendly buildings are completely cost-effective and do not require large maintenance costs, which saves money. They save resources by using energy, water and materials more efficiently over their life cycle [4, p. 369]. 
Today, the share of green buildings in the total number of new buildings in the European Union reaches $20 \%$ and the number of such buildings is constantly growing. The EU environmental policy is focused on developing a long-term development strategy for the construction industry. These problems are reflected in a special EU regulation covering services (CPR - Construction Products regulation, 2011), where health and safety issues are identified as key throughout the investment and construction cycle. The main direction of sustainable construction in the EU is the gradual transition from the construction of new buildings to maintenance and reconstruction of the existing stock of buildings and structures, which is probably due to modern EU energy saving policy. The main tool for assessing environmental performance to achieve the goals of sustainable construction is an automated method for assessing the life cycle (English — Life Cycle Assessment, LCA), developed by the International Organization for Standardization (ISO) [4, p. 369].

Developed countries have been effectively implementing green construction technologies for many years, and the pace of development in this area is accelerating every year. In Ukraine the implementation of the concept of green building is at an early stage. Single construction projects with green technologies have been implemented in our country. In 2013 the Green Building Council (UaGBC) was registered in Ukraine. The main purpose of the Council is to unite organizations and professionals who adhere to the principles of green building in their activities. In 2016 Ukraine joined the World Green Building Council [3, p. 57].

According to Bilyk O.A., the development of green building in Ukraine is possible only if:

- development of a normative-legal act, which would establish requirements for the design of houses and settlements according to ecological criteria, as well as state-building norms, which establish rules for the design of houses with a level of energy consumption close to zero;

- stimulating the development of production of efficient and environmentally friendly equipment and materials, in particular the introduction of environmental taxes on construction materials;

- raising the professional level of specialists engaged in construction, operation and design;

- development of scientific support of green construction;

- introduction of a course on green building in the educational process;

- organization of design and construction of buildings and structures of high environmental and energy efficiency;

- development of measures to increase the demand for green buildings, in particular the development and implementation of programs for the formation of environmentally oriented demand and increase environmental literacy of consumers, etc. [3, p. 57].

\section{CONCLUSIONS}

Thus, green building is one of the most effective innovative ways to ensure sustainable development of society and increase the sustainability of the living environment. Its application in practice allows to achieve such important goals as: 1) efficient use of energy resources; 2) reduction of negative impact on the environment; 3 ) creating comfortable living conditions.

Environmental building is a type of building and maintenance whose main objective is to reduce energy and material consumption throughout the life cycle of a building: from site selection to design, construction, maintenance, repair and demolition.

Unfortunately, our country is taking only the first steps towards sustainable construction. The main obstacle is the high start-up costs. But we need to understand today that green building is not just another fashionable trend, but a real need that $100 \%$ will pay off. The experience of many developed countries of the world has shown that construction contributes to solving the pressing problems of humankind today and is also important in achieving the Sustainable Development Goals.

\section{REFERENCES}

1. Kryvomaz, T.I., Savchenko, A.M. (2021). Znyzhennia vplyvu budivelnoi haluzi na klimatychni zminy shliakhom vprovadzhennia pryntsypiv zelenoho budivnytstva [Reducing the impact of the construction industry on climate change through implementing the principles of green building]. Ekolohichna bezpeka ta pryrodokorystuvannia - Ecological safety and nature management, 1(37), 55-68. DOI: https://doi.org/10.32347/2411-4049.2021.1.55-68 URL: http://es-journal.in.ua/article/view/228419 [in Ukrainian].

2. Orlovska, Yu.V., Vovk, M.S., Chala, V.S., Mashchenko, S.O. (2017). Ekonomichna polityka YeS z pidtrymky zelenoho zhytlovoho budivnytstva: monohrafiia [EU economic policy in support of green building: monograph]. Dnipro: 2017. 148 p. URL: http://www.intecon.dp.ua/wp-content/uploads/2017/09/Orlovska-Vovk-Chala-Maschenko-econom.pdf [in Ukrainian]. 
3. Bilyk, O.A. (2016). Zelene budivnytstvo: kontseptsiia, prychyny ta tendentsii rozvytku [Green building: concept, reasons and development trends]. Naukovyi visnyk Khersonskoho derzhavnoho universytetu. Cer.: Ekonomichni nauky - Scientific Bulletin of Kherson State University. Series: Economic Sciences, 20, 1, 53-57. URL: http://www.ej.kherson.ua/journal/economic_20/1/15.pdf [in Ukrainian].

4. Orlovska, Yu.V., Yakovyshyna, T.F., Orlovskyi, Ye.S. (2016). Zelene budivnytstvo yak skladova polityky YeS shchodo rozvytku tsyrkuliarnoi ekonomiky [Green building as a component of EU policy on the development of the circular economy]. Skhidna Yevropa: ekonomika, biznes ta upravlinnia - Eastern Europe: Economy, Business and Management, 5 (05), 365-371. URL: http://www.easterneurope-ebm. in.ua/journal/5_2016/70.pdf [in Ukrainian].

5. Mashchenko, S.O., Vovk, M.S., Aliiev, R.A. (2016). Teoriia ta metodolohiia zelenoho budivnytstva [Theory and methodology of green building]. Ekonomichnyi prostir - Economic space, 113, 220-230. URL: http://www.irbis-nbuv.gov.ua/cgi-bin/irbis_nbuv/cgiirbis_64.exe?I21DBN=LINK\&P21DBN=UJRN$\& Z 21 \mathrm{ID}=\& \mathrm{~S} 21 \mathrm{REF}=10 \& \mathrm{~S} 21 \mathrm{CNR}=20 \& \mathrm{~S} 21 \mathrm{STN}=1 \& \mathrm{~S} 21 \mathrm{FM} \overline{\mathrm{T}}=\mathrm{ASP} \_$meta $\& \mathrm{C} 21 \mathrm{COM}=\mathrm{S} \& 2 \_\mathrm{S} 21 \mathrm{P} 03=\mathrm{F}-$ ILA $=\& 2 \_S 21 S T R=$ ecpros_2016_113_23 [in Ukrainian].

6. Danyliuk, M.M., Dmytryshyn, M.V. (2020). Zelene budivnytstvo u dosiahnenni staloho rehionalnomu rozvytku [Green building in achieving sustainable regional development]. Aktualni problemy rozvytku ekonomiky rehionu - Current problems of economic development of the region, issue 16, volume 1, 153-162. DOI: 10.15330/apred.1.16.153-162. URL: https://www.researchgate.net/publication/348219444_GREEN_BUILDING_IN_ACHIEVING_SUSTAINABLE_REGIONAL_DEVELOPMENT [in Ukrainian].

7. The benefits of green buildings. URL $\bar{L}$ : https://www.worldgbc.org/benefits-green-buildings [in English].

\section{ЗЕЛЕНЕ БУДІВНИЦТВО ЯК НАПРЯМ СТАЛОГО РОЗВИТКУ: СУТНІСТЬ, ЗАВДАННЯ, ПРИНЦИПИ, ПЕРЕВАГИ, ПЕРСПЕКТИВИ}

В.Ю. Білотіл науковий співробітник Інститут агроекології і природокористування НААН (м. Київ, Україна) e-mail: Walya@i.ua

Будівельна галузъ відіграє важливу ролъ у досягненні Цілей сталого розвитку ООН та зменшенні впливу на кліматичні зміни через впровадження принципів зеленого будівництва, тому стаття присвячена саме извому виду будівництва як актуальному напряму сталого розвитку.

Охарактеризовано взаємовплив кліматичних змін та будівелъної діяльності. Проаналізовано завдання та принциипи екологічного будівництва. Досліджено економічні, екологічні та сочіальні переваги зеленого виду будівниитва. Охарактеризовано різницю між традииійним та зеленим будівництвом. Розглянуто нинішній стан розвитку сталого будівництва в Україні та світі. Визначено перспективи зеленого будівництва в Україні. Доведено актуальність та необхідність його впровадження в нашій країні.

Ключові слова: будівелъна галузъ, глобалъні зліни клімату, екологічне будівництво, зелена економіка, Цілі сталого розвитку.

\section{ЛIТЕРАТУРА}

1. Кривомаз T.I., Савченко А.М. Зниження впливу будівельної галузі на кліматичні зміни шляхом впровадження принципів зеленого будівництва. Екологічна безпека та природокористування. 2021. № 1(37). C. 55-68. DOI: https://doi.org/10.32347/2411-4049.2021.1.55-68 URL: http://es-journal. in.ua/article/view/228419 (дата звернення: 26.05.2021).

2. Орловська Ю.В., Вовк М.С., Чала В.С., Мащенко С.О. Економічна політика ЄС з підтримки зеленого житлового будівництва: Монографія. Дніпро, 2017. 148 с. URL: http://www.intecon.dp.ua/wp-content/uploads/2017/09/Orlovska-Vovk-Chala-Maschenko-econom.pdf (дата звернення: 26.05.2021).

3. Білик О.А. Зелене будівництво: концепція, причини та тенденції розвитку. Науковий вісник Херсонсъкого державного університету. Сер.: Економічні науки. 2016. Випуск 20. Частина 1. С.53-57. URL: http://www.ej.kherson.ua/journal/economic_20/1/15.pdf (дата звернення: 01.06.2021).

4. Орловська Ю.В., Яковишина Т.Ф., Орловський Є.С. Зелене будівництво як складова політики ЄС щодо розвитку циркулярної економіки. Східна Європа: економіка, бізнес та управління. 2016. № 5 (05). C. 365-371. URL: http://www.easterneurope-ebm.in.ua/journal/5_2016/70.pdf (дата звернення: 01.06.2021).

5. Мащенко С.О., Вовк М.С., Алієв Р.А. Теорія та методологія зеленого будівництва. Економічний простір. 2016. № 113. C. 220-230. URL: http://www.irbis-nbuv.gov.ua/cgi-bin/irbis_nbuv/cgiirbis_64.exe? I21DBN=LINK \&P21DBN=UJRN\&Z21ID $=\& S 21 \mathrm{REF}=10 \& \mathrm{~S} 21 \mathrm{CNR}=20 \& \mathrm{~S} 21 \mathrm{STN}=1 \& \mathrm{~S} 21 \mathrm{~F}$ $\mathrm{MT}=\mathrm{ASP}$ meta\&C21COM=S\&2_S21P03=FILA=\&2_S21STR=ecpros_2016_113_23 (дата звернення: $01.06 .2021)$.

6. Данилюк M.M., Дмитришин М.В. Зелене будівництво у досягненні сталого регіональному розвитку. 
Актуалъні проблеми розвитку економіки регіону. 2020. Bun.16. T. 1. C. 153-162. DOI: 10.15330/ apred.1.16.153-162. URL:https://www.researchgate.net/publication/348219444_GREEN_BUILDING_IN_ACHIEVING_SUSTAINABLE_REGIONAL_DEVELOPMENT (дата звернення: 01.06.2021).

7. The benefits of green buildings. URL: https://www.worldgbc.org/benefits-green-buildings (дата звернення: 26.05.2021).

\section{ВІДОМОСТІ ПРО АВТОРА}

Білотіл Валентина Юріївна, науковий співробітник, Інститут агроекології і природокористування НАAН (вул. Метрологічна, 12, м. Київ, Україна, 03143; e-mail: Walya@i.ua)

\section{HOBERE}

14 лютого було підписано Меморандум про взаєморозуміння в сорері землеустрою між Держгеокадастром і Міністерством зміни клімату та навколишнього середовища Об'єднаних Арабських Еміратів. Меморандум підписали в рамках візиту української делегації на чолі з президентом Володимиром Зеленським у ОАЕ.

Відомства будуть співпрацювати на предмет практик «використання і охорони сільськогосподарських земель, збереження відтворення та підвищення родючості грунтів, впровадження та вдосконалення електронних послуг в сорері землеустрою, моніторингу екологічного стану земель і грунтів в результаті впливу зміни клімату та негативних процесів». Меморандум набирає чинності з дня його підписання на п’ятирічний період з автоматичним продовженням кожні 5 років. 